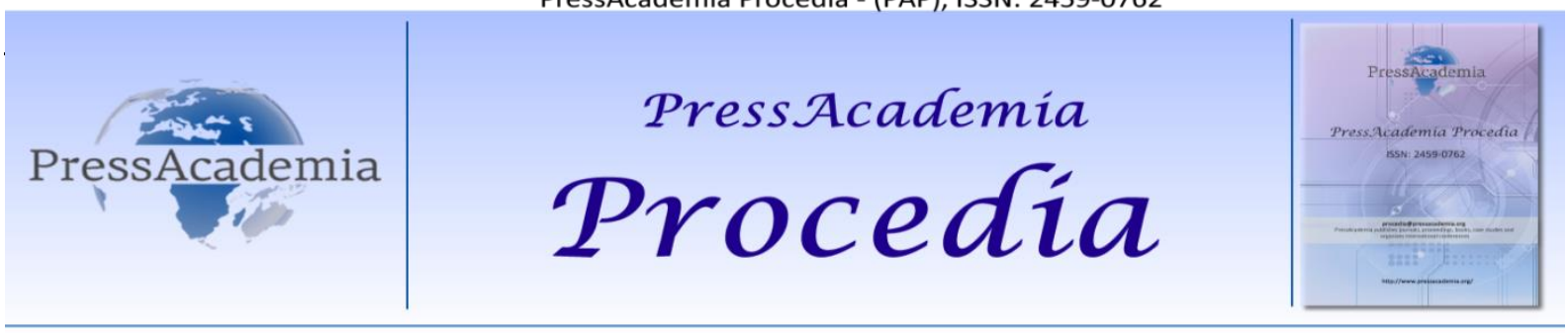

Global Business Research Congress (GBRC), May 24-25, 2017, Istanbul, Turkey.

\title{
TERRORIST ATTACKS IN AVIATION: AN ANALYSIS OF ATATURK AIRPORT ATTACK ON $28^{\text {th }}$ OF JUNE 2016
}

\section{DOI: 10.17261/Pressacademia.2017.681 \\ PAP- GBRC-V.3-2017(108)-p.1012-1018}

\author{
Mevlut Uzulmez ${ }^{1}$, Savas S. Ates ${ }^{2}$ \\ ${ }^{1}$ Erciyes Üniversitesi, Havacılık Ve Uzay Bilimleri Fakültesi 38039, Kayseri, Turkey. mevlutuzulmez@erciyes.edu.tr \\ ${ }^{2}$ Anadolu Üniversitesi, Havacılık ve Uzay Bilimleri Fakültesi İkieylül Kampüsü 26470, Eskişehir, Turkey. ssates@anadolu.edu.tr
}

\section{To cite this document}

Uzulmez, M. and S.S.Ates, (2017). Terrorist attacks in aviation: an analysis of Ataturk Airport attack on $28^{\text {th }}$ of June 2016 . PressAcademia Procedia (PAP), V.3, p.1012-1018.

Permemant link to this document: http://doi.org/10.17261/Pressacademia.2017.681

Copyright: Published by PressAcademia and limited licenced re-use rights only.

\begin{abstract}
For the last century, terrorism has shown itself in many different field. One and maybe the most effective field is aviation sector. Natural structure of aviation is international which is known and operated by different countries at the same time. Because of its function, airports are the most strategical places for country, securing these areas are also extremely crucial. Thus, airports are number-one target for sensational terrorist attacks. In this paper, Atatürk Airport attack on $28^{\text {th }}$ June 2016 has been studied and outcomes are discussed for more sophisticated security systems. In the first stage of this paper, the theoretical research of terrorist attacks and related terms have been examined. In the second part, with the data acquired by study in practice airport attack on 28 June 2016, reasons of attack, precautions after explosion and negative consequences have been stated with articles. In the final part of the study, the actual and possible results of airport attack have been discussed and evaluated by employee working at airport by means of semi-structured interview and in-depth analysis. With analyzing the obtained results, the impact of terrorist attack at Atatürk Airport on governmental and personal level has been identified and on the purpose of improvement of system some recommendations have been made.
\end{abstract}

Keywords: Airport attacks, airport security, terrorist attack, aviation security, precautions for airport JEL Codes: L93, R41, L98.

\section{INTRODUCTION}

Globalization, changing world order and advances in communication technologies have made terrorism one of the most serious international problems of today's world. The aviation industry, one of the fastest growing industries in the world economy, is becoming a clear target of terrorist attacks because of its sensitivity to crises, terrorism and violence Terrorist acts that have been on the world agenda in recent times also directly or indirectly affect the aviation industry, which is an important part of the global economy (GÜREL, 2008, pp. 32-35). Many countries, including Turkey, are still living under the threat of terrorism and the aviation industry and national economies are seriously hurt by the terrorist attacks, which have lost the lives of many innocent people. Therefore, terror attacks and the concept of terrorism continues to be one of the most crucial factors affecting the aviation movements on a global scale in the negative direction (AÇIL, 2010, pp. 4-8).

Terrorism can be expressed as an attempt to frighten and intimidate society in a systematic way using all kinds of violence. From this definition, we can say that civil aviation has some specific reasons when it is determined as a primary target by terrorist organizations. Social damage after the September 11 attacks in the United States proves what kind of echo the planned actions may bring to the aviation sector (AÇIL, 2010, pp. 100-104). In the light of the negative consequences it has caused, acts of terror directly affect not only the sector but also the sense of social order, economy, politics and security. Unfortunately; When recent actions taken in recent times are taken into consideration, result shows that terrorist groups succeeded in overcoming existing security protocols.

The September 11, 2001, terrorist attack is the first major event that the globalizing world has experienced in the new century. Although it seems to be a local phenomenon, the terrorist attack has global dimensions, both in terms of its fiction and its consequences. However, the impact created by the attacks has shown itself particularly in the context of security 
perceptions. Terrorist attack has not only shown that air transportation safety is an integral part of national security, but the great fear and insecurity that arises as a result of attacks ruin the whole credibility of air transportation replaced.

\section{LITERATURE REVIEW}

\subsection{Terror and Its Purposes and Reasons}

\subsubsection{Terror Concept}

This term is quite complicated to be identified in a specific field. If we describe it as a crime: it should be applied as course of real action so that evidences must be collected and suspects must be investigated for any sort of intentional action. On the other hand, if this term used as warfare more realistic and administrative actions ought to be in charge such as military force and ultimatum against the group or perpetrator (YAZĞAN, 2002). In addition, terrorism is a term that refers to the use of pressure, intimidation and all forms of violence towards civilians, official, local and general government in order to achieve political, religious and/or economic goals (tr.vikipedia.org, 2017). "Terror" and "Terrorism" are different concepts. Terror; It can be defined as organized and unregulated acts of violence. Terrorism is an activity that targets the current political power and regime, based on the acts of violence by more than one person who is organized around an ideology that has a political element or/and ideology, which tries to destroy the current system by violence. (Jandarma.gov.tr, 2017)

\subsubsection{Purpose of Terror}

There are four type of objective to commit a terrorist attack. These can be classified as sociocultural, economic, political and physiological objectives.

\subsubsection{Sociocultural Purposes}

In society, disturbing unity and integrity by confronting groups with different cultural backgrounds and worldviews is one of main objective of these actions. Abuse of ethnicity has been quite popular as a source of terrorism. Terrorist organizations attach great importance to propaganda activities in order to influence public opinion. Mass media are used effectively in these activities (terororgutleri.com, 2015). These groups try to confront the mentioned groups by making use of these differences and try to disrupt the unity and integrity of the society. (KAYAOĞLU, 2017)

\subsubsection{Economic Purposes}

Terror is a great danger especially for economically weak countries. The economies that are used to combat terrorism, which have to be spent on planned activities for the development of the country, are causing great damages. Terrorist organizations have their economic objectives among the attack strategies, and therefore their destruction of the country is the most important goal. Especially for tourism countries, airports attacks affect tourism terribly because of the impression of security level. Therefore, damaging tourism so that decreasing the economic welfare can be counted as one of the major purpose for terror groups. At this point, the people of the economically weakened state will show a great reaction and the country will be dragged into turmoil, and the terrorist organization will benefit from this environment at the maximum level. (terororgutleri.com, 2015)

\subsubsection{Political Purposes}

The main aim of terrorism can be stated as destroying the targeted regime, system, violence, and establishing a new administration in line with its own ideologies. The primary goals of the actions of the terrorist organizations in the first instance are to weaken the political power in the eyes of the people and gradually weaken the state's spiritual authority. Thus, it will be tried to show that the administrators in the head of the state are not capable, and the alternative of the terrorist organization will be presented to the public (terororgutleri.com, 2015). The importance of governmental responsibility towards terrorism cannot be underestimated. If the reorganization is weak, it may become more striking in the presence of terror. (HUTCHINSON, 1972)

\subsubsection{Physiological Purposes}

The fact that terrorist organizations are involved in acts of violence without regard to any specific goal undermines the general peace and prosperity of the society and creates a network of fear. Thus, the confidence of the society in the state is shaken. The people who cannot predict exactly what to do in such an environment can be dragged into a confusion because they can give extraordinary reactions. (terororgutleri.com, 2015)

\subsection{Reasons of Terror}

There are many different and -at the same time- related reasons for these illegal actions. However, in order to classify them in a certain way, those reasons have been gathered into four groups as well as the purpose of terrorism: economic, sociocultural, political and physiological. In order to understand the basic causes of terrorism, the following two problems must be answered:1) Why are the negativities brought about by modernization and globalization not being seen as anonymous but burdened by some individuals, institutions, institutions and states?2) Why do some groups engage in acts of violence against people and groups they see as responsible for their negatives? (YEL, 2006) 


\subsubsection{Economic Reasons}

The economy, which is one of the indispensable elements of social life; When it is broken and shaky, it may be easily the influence on terrorist incidents. The resulting imbalance, injustice and corruption create a non-satisfied group, in which case terrorism comes into play. Because terrorist organizations obtain better support and personnel from the economically disadvantaged sector. It is tried to be exploited as much as possible by making propaganda material (HAVABULUT, 2007).

\subsubsection{Sociocultural Reasons}

Terrorism, which is essentially a social event, is undoubtedly a multifaceted and complex problem. While treating terror as a social event, it is necessary to examine the value judgments, habits, traditions and customs of the society. In this context, rapid changes in social values can lead to increased deviations and conflicts in society. During this period of change, distress, depression and chaos; It both nourishes terrorists and violent opponents and causes them to influence society (HAVABULUT, 2007).

\subsubsection{Political Reasons}

This concept can be divided into internal and external political reasons. External political causes can be explained by reducing an individual's power, using it as a blackmail component, supporting its own ideology to other countries and supporting terrorist groups in the country. Moreover, Internal political causes are defined as power is not used well or that the internal political groups / parties have quarreled over the country's interests and that the resulting lack of authority and terrorist elements can encourage terror to grow even more. The fact that the political powers do not act in accordance with the principles they defend, their failure on fulfilling their promises also causes a crisis of confidence and the people are being dragged into polarization by opening the political formations (HAVABULUT, 2007). States' characterization of acts of violence differs not only from their ideological approach but also from their political interests (AKÇA, 2013).

\subsubsection{Physiological Reasons}

Besides the social dimensions, there are a number of psychological reasons that arise from the social structure, or psychological state of the person himself which has a great place in the formation and application of terror. People can look for different options with the psychology of not being able to meet their basic needs. The difficulty of economic conditions affects people both psychologically and morally as well as materially, and this issue is being used by terrorist organizations. In other words; some people do not see their personal skills, their status, role and location appropriate. They use examples of behavior that involve aggressive behavior and acts of violence in order to earn respect (HAVABULUT, 2007).

\subsection{Terrorism in Aviation Sector}

Aviation sector is an international security area where both threats and vulnerabilities are known, and prevention processes have already been considered. The technological advancement undoubtedly leads to a widespread increase in terrorist ammunition. The terrorists' political goals are spreading through the world media network, and new and lucrative targets are foreseen for terrorist activities. The development of the civil aviation network has also made terrestrial and national borders a major target for terrorist activities (LINZ, 2012).

For more than seven decades, terrorism is targeting aviation sector especially commercial flights in order to take even more attention. Because aviation sector represents the prestige and global pride for most of countries. There are lots of options for attackers such as hijacking, bombing aircraft or airport lounge and more recently turning aircraft into guided missiles aiming to specific social and/or financially important place. Tragic event of September 11, 2001 has gathered all the focus on aerial terrorism all around the world (DEMPSEY, 2002).

\subsubsection{Precaution Against Aviation Attacks}

After September 11, all the nations have agreed that there must be certain rules, improvement and change at some point of aviation sector. At international basis, solutions and reactions have been suggested and new conventions have taken place for identifying, measuring and punishing responsible person or organizations.

Tokyo convention, Montreal convention, Hijacking convention, Rome convention, Bonn agreement 1978, Montreal protocol of 1988 and G-7 and Lyon summits can be counted as major regulations at international level. Each country is at large to participate to those conventions however since aviation is an international activity, member states usually consider nonmembers inappropriate to operate (SWEET, 2008, pp. 38-48).

Another type of precaution for passenger is securing the terminal area with sophisticated devices. Metal detectors, handheld body scanners, metal detectors, X-ray inspection units, passive and active millimeter-wave imaging, prior X-ray explosive detection devices, three-dimensional imaging and bottled liquid scanners can be counted as security devices on the way of improving security level for airports. While these systems are set up, international standards for radiation must be applied to protect human health (SWEET, 2008, pp. 191-210).

Securing the cargo is also essential against planned terrorist actions. Cargo carrier's responsibility is quite high when dangerous goods considered over standard security work. Suicides, baggage tags, airport lockers, airmail security, unknown 
shipper are main risks in cargo department. All detection and applications must be according to the international cargo standards (SWEET, 2008, pp. 220-230).

\subsubsection{Impact of Terrorist Attack on Passenger and Employee}

Along with globalization, the integration of financial markets caused the consequences of economic uncertainty such as terrorism emerging on an international scale. When the number of terrorist acts and the number of people who lost their lives in terror are evaluated together, it is evident that international terrorist acts have been designed more lethal each year. It is also important to understand the economic effects as well as other effects of the tragedy. Because the precondition of a successful anti-terror policy comes from understanding terrorism quality, structure and effects correctly. With its economic and social consequences, terrorism disrupts the functioning of the international financial system and seriously damages the national economy. Terrorism increases transaction costs, reduces investments and increases public spending. Increased risk and uncertainty due to terrorism also limits employment opportunities. In addition, terrorism, which undermines the tourism sector -significant part of aviation- with its high multiplier effect, also causes the country to lose significant sources of income (ALP, 2013).

First and the most important impact of terrorist attack is human death and injures. Especially when this kind of actions occur in the air, the result can be catastrophic in case of air crash. If we take September 11, consequences were almost three thousand of dead people and more than ten billion dollars financial damage. This clearly shows that terrorism in the air can be extremely severe (vikipedia, 2017). On the other hand, foreign tourism revenues are the main source of foreign exchange for many emerging economies. When there is a sudden contraction in the sector due to the high multiplier effect of the tourism sector, harder effects are observed in the economy as a whole. Terrorists have also noticed this importance of tourism over time. Tourists are among the important targets of terrorist organizations because of the big echoes in local and foreign press. In this way, terrorists increase their chances of realizing the interest of the media and therefore of propaganda. Terrorist organizations are trying to reduce the foreign exchange inflow to the country by intimidating tourists' eyes and put pressure on the government at this point (ÜNLÜ, 2009).

Second impact of these attacks is economical one. Essentially, the factor that increases the transaction costs is not terrorist attack itself, but the precaution efforts against terrorist. Protection against terrorism must be taken in the whole country because it is uncertain where terrorist organizations will be able to attack. For example, customs controls are increased, the number of security officers is increased, and more advanced detectors are being received at airports. This not only increases the costs, but also slows down the operations and becomes the burden on the economy (ALP, 2013). Moreover, if the topic is taken into account in terms of foreign direct investment, it can be considered that terrorism has a negative effect on such investments. The traditional approach is that the capital from the country will escape because of the loss of trust of foreign investors (TORUM, 2011).

Final and unmeasurable effect is shown as social and psychological changes and collapse on experienced people. It creates a serious, shocking and violent impact on the individual and society. Terrorist events negatively affect the mental health of individuals and families as well as social well-being, security and social function. (HASANOĞLU, 2015). Terrorism is aimed at reducing social mobility in the society and making people avoid social hype. Fear of the places of entertainment is an economic shock as well. Even though new events do not come after the terrorist events, people can live anxious and fearful life with the effects left by the previous ones. Traumatic events in people who are living, witnessed and shared from afar, leave the trauma effect. The spiritual balance and life integrity of an individual who has experienced trauma may be impaired. It may be seen as a social trauma if terrorism is to be assessed in this respect, and such a society may be lacking in the fight against terrorism. For this, terrorist acts are carried out in places where there are more civilians and in places that cause collective deaths and more socially sensitive (KARA, 2017).

\section{DATA AND METHODOLOGY}

Main objective of this study is to evaluate the actual and possible result of terrorist attacks aiming airports. As a result of this study, it is hoped that this study may help understanding the physical and psychological effect of attacks on both passenger and employee working for airlines or airport.

At the theory part, national and international manuals, previously written doctoral and master's thesis and number of essay related to topic have been examined. In addition to that, national and international feedbacks from head of different states, news and interviews data about $28^{\text {th }}$ of June 2016 were collected.

This study has been implemented at istanbul Atatürk Airport and with one person who has actually been in the middle of explosion because of the time and cost limits. The names employee has been coded because of the fact that he requires his name censored.

Implementation has been made by semi-structured interview and in case of requirement of more detailed information indepth analysis has been used as a secondary resource. In the light of answer we have got, new questions have been added and some of them have been changed. 


\section{FINDINGS AND DISCUSSIONS}

A terrorist attack, consisting of shootings and suicide bombings, occurred on 28 June 2016 at Atatürk Airport in Istanbul, Turkey. Gunmen armed with automatic weapons and explosive belts staged a simultaneous attack at the international terminal of Terminal 2. Forty-five people were killed, in addition to the three attackers, and more than 230 people were injured. Media reports indicated that the three attackers were believed by Turkish officials to have come from Russia and Central Asia. Turkish officials said the attackers were acting on behalf of the Islamic State of Iraq and Levant and had come to Turkey from ISIL-controlled Syria. Commentators suggested that the attacks may have been related to stepped-up pressure against the group by Turkish authorities. No one claimed responsibility for the attack (encyclopedia, 2017).

\section{Attack Time Analysis of Ataturk Airport}

At the entrance of Atatürk Airport, the taxi passed through the search point where the police turned suspicious vehicles without any hindrance. Terrorists landed in front of International Arrivals Terminal. After opening the suitcase, putting on their jackets and jackets they had pulled out and hiding the Kalashnikov weapons, one of them went to the parking lot, one went international arrival terminal and other one went international departure terminal.

At the same time, three security guards entering the parking lot were reported to be policemen suspicious of the jackets and coats they wore despite the warmth. A civilian police officer approached the terrorist who was on his way to the door to inquire about his identity. The terrorist opened fire and the police got wounded from his shoulder. When the gunshot sounded from the car park, a live bomb exploded in front of the arriving terminal, where passengers landed on the vehicles. While there was a great panic, many people, including three taxi drivers, lost their lives at that spot.

The second live bomb exploited the panic by bombarded by the parking lot, entered with Kalashnikov by firing to the departure gate of entrance $A$. The live bomb that entered the terminal from the $x$-ray devices where unarmed security officers stands managed to progress to the CIP section. Police officer Y.D, who checked the entrances in front of the passport control point, took the cover of the wall. When he was going to shoot right through the front, the terrorist acted early and shot the police officer. Police officer fired 10 hands as wounded. The terrorist's weapon fell away, In the meantime, the police officer shouted "Bomb" to warn passenger around him, and the police officer had to walk away when he saw live bomb was ready to pull the pimp. Suicide bomber hit the button and exploded the bomb. Thanks to the police officer's warning, no one died in that terrific explosion that pierced the concrete floor.

The third fire-fighting bomber who opened the first fire at arrival door to the policeman was planning to create a massive damage near the customs point where the escaped people were piled up. The terrorist fired his gun over the panicked passengers and was shot by Umut Sakaroğlu, a customs officer in front of Simit Palace. Umar Sakaroğlu became a martyr when the suicide bomber exploded himself.

\section{Reactions and Comments of Head of States After Airport Attack}

One day after the attack, on June 29, 2016, the Turkish government declared a one-day national mourning period, and the flag was cut down in all the representations and official institutions in Turkey and abroad.

President of the Turkish Republic of Northern Cyprus Mustafa Akıncl; "Wherever this terror comes from, it is strongly condemned whatever the source is." He also stated that "this is precisely the significance of the emergence of Turkey's foreign relations, which is beginning to improve." On June 29, 2016, a one-day national mourning for solidarity with Turkey was declared.

United States President Barack Obama called President Erdogan by phone and said that he strongly condemned the terrorist attack on Istanbul Atatürk Airport and conveyed his pleasures to lose his life. US Secretary of State Kerry said that they continued to receive information about the terrorist attack that took place at Atatürk Airport. "We are investigating what happened and who performed it," Kerry said of the explosion at the Atatürk Airport. The first challenge is to confront non-state, pro-violent actors."

Chancellor Angela Merkel; As European Union leaders, they expressed their shock and said, "I want to convey to all Turkish people that we are united in the fight against terrorism and that we will support each other."

Russian President Vladimir Putin called Erdogan on the phone and conveyed the news about the attack.

The United Nations Secretary Ban Ki-mun said in a statement he made through his spokesman that "He expressed his wishes to the families of those who lost their lives in the terrorist attack, the Turkish government and the people, and urgent emergency healing."

NATO Secretary Jens Stoltenberg strongly condemned the attack on the written statement, saying: "... All NATO allies are in solidarity with Turkey, and with terrorism, we are all in a commitment to fight." In addition, 28-member nations flag in front of the NATO headquarters in Brussels were half-mast to commemorate their lost.

\section{Precautions and Devices After Attack}

- Liquid Explosive Detector Machine 
- As a new security measure at Atatürk Airport, concrete barriers were placed in front of the domestic and international terminals.

- Atatürk Airport's private security service TAV private security officers started patrolling with MP-5 type automatic pistol. Bomb deter dogs were increased in number and increased from the police directorate.

\section{Effect of Attack on Flights}

Some of the scheduled flights on the day of the explosion were delayed, canceled, redirected to spare spaces. But four hours later at around $3 \mathrm{pm}$ the airport was reopened to traffic. The environmental and financial impact of the explosion at Atatürk Airport literally has been covered a month after.

\section{Psychological Conditions of Employees and Passengers After Attack}

The traces of the terrible terrorist attack that caused more than 230 people to be injured in the death of 45 people at Istanbul Atatürk Airport were erased, but it was very difficult to forget the wounds that our souls experienced. In addition to those directly affected by the incident, 50,000 people working at Ataturk Airport were the targets of this attack in spiritual terms. It was stated that airport employees were concerned that there could be many new events that would disturb the sense of security that everyone affected by the attack had to receive preventive psychological support and special psychological training programs for such emergency situations.

Most people exposed to trauma related to Attack at Ataturk Airport can develop Posttraumatic Stress Disorder (PTSD) and major depression. These people need special treatment for their healing. The number of people suffering from these disorders; Depending on how close the person is to the scene at the time of the event. Because the attack was caused by severe injury, death and destruction, it was always the people directly affected by the accident who were the most severely traumatized.

\section{CONCLUSION}

Terrorist attacks are one of the most dangerous and damaging factor of aviation sector. These attacks are not only affecting current schedule but also decreasing potential demand because of the uncertainty and security concern. As airports represent its country's development and security level, they are targeted by evil-minded people in order to disgrace or get desired attention. Any attack against to airports directly decreases general impression of that country. Therefore, governments should take serious precaution for potential ones.

The airports that are front-line in the world's media are the targets of terrorist propaganda attacks. The airports are the countries' ports that open to the foreign countries and the airport is the place where the tourist density is extremely high. Freedom of travel which is one of the basic freedoms of people is being disturbed. Surviving attacks also reveal that terrorist organizations are targeting tourism as a secondary or main goal.

Atatürk Airport attack on $28^{\text {th }}$ June 2016 has shown that there could be severe consequences by planned and large-scaled attack unless sufficient equipment and information technology systems are applied. Consequences can be emotional and psychological as much as financial and physical. Hence, recovery period extends in different dimensions. While it requires high amount of money to replace damaged devices, recovery period of mentally damaged people may need several years.

With the assistance of technology, everyday new methods of attack are coming forward. Thus, it is essential that adapting security systems to changing dangerous attempts. Airports are required to take the necessary security measures within the framework of ICAO and ECAC rules. Restricted sections of passengers and public places to take precautions against illegal acts should be sufficiently supervised by the security officers. It is impossible to completely eliminate international civil aviation from illegal activities because of the wide and multiplicity of the physical areas to be protected and the numerical size of the employees and the passengers. However, it is quite possible to determine where the mistakes have been made in the past incidents and to take lessons from them and to prevent the likely future mistakes and thus the attacks. The main purpose of aviation security will be approached with the increase of preventative applications.

\section{REFERENCES}

Akça, M. (2013). Terörizm dosyası: V.terörizmin tanımlanmasındaki sorunlar ve nedenleri. Karabük: Karabük Universitesi, uluslararası ilişkiler.

Alp, I. A. (2013). Terörün ekonomik etkileri. Uluslararası Güvenlik ve Terörizm Dergisi, 4(1), 1-10.

Dempsey, P. S. (2002). Aviation security: the role of law in the war against terrorism. Columbıa Journal of Transnatıonal Law, 649-651. 
Encyclopedia, W. (2017, 04 24). 2016 Atatürk Airport Attack. wikipedia.com:

https://en.wikipedia.org/wiki/2016_atat\%c3\%bcrk_airport_attack adresinden alındı

Hasanoğlu, A. (2015, 10 14). Terörizm ve etkileri. radikal: http://www.radikal.com.tr/yazarlar/therapiagroup/terorizm-ve-etkileri-1451094/ adresinden alındı

Havabulut, G. (2007). Terörizmin değişen yönü ve el kaide'nin sosyo-kültürel yorumu. Ankara: Ankara Universitesi.

Hutchinson, M. C. (1972). The concept of revolutionary terrorism. Virginia: Sage Publications, Inc.

jandarma.gov.tr. (2017, 02 08). Terör, terorizm ve terör örgütlerinin amacı. jandarma.gov.tr:

http://www.jandarma.gov.tr/asayis/ter.s/teror_terorizm_teror_orgutlerinin_\%20amac\%c4\%b1.htm adresinden alındı

Kara, S. (2017, 04 12). Terörün psikolojik etkileri. psikolog selin kara: http://www.selinkara.com/terorun-psikolojik-etkileri/ adresinden alındı

Kayaoğlu, H. S. (2017, 01 03). terör ve terörizmin amacı nedir? hasansabrikayaoglu.com: http://www.hasansabrikayaoglu.com/teror-veterorizmin-amaci-nedir/ adresinden alındı

Linz, M. (2012). Scenarios for the aviation industry: a delphi-based analysis for 2025. Journal of Air Transport Management, 28-35.

Sweet, K. M. (2008). Aviation and Airport Security: terrorism and safety concern. London: CRC press.

terororgutleri.com. (2015, 03 13). terörün amaçları. terör örgütleri: http://www.terororgutleri.com/terorun-amaclari/ adresinden alındı

Torum, O. (2011, 09 15). 11 Eylül 2001'den sonra neler değişti? airporthaber.com: http://www.airporthaber.com/kose-yazilari/11-eylul2001den-sonra-neler-degisti-929y.html adresinden alındı

tr.vikipedia.org. (2017, 02 07). terörizm. vikipedia: https://tr.wikipedia.org/wiki/ter\%c3\%b6rizm adresinden alındı

Unlü, S. (2009). 11 Eylül olaylarının uluslararası sivil havacılık güvenliğine etkileri. Konya: Selçuk Universitesi.

Vikipedia. (2017, 01 18). 11 Eylül saldırıları. vikipedi, vikipedi, vikipedi.

Yazğan, S. (2002). terrorism and the international system. istanbul: marmara üniversitesi.

Yel, A. M. (2006). The basic reasons of terrorism. Istanbul: Fatih Universitesi. 